\title{
Kształcenie akademickie w warunkach zagrożenia epidemicznego COVID-19 - perspektywa studentów i wykładowców
}

Academic education in conditions of the COVID-19 epidemic threat - the perspective of students and lecturers

\begin{abstract}
Streszczenie
Głównym celem przeprowadzonych badań było poznanie opinii studentów i wykładowców polskich uczelni (publicznych i niepublicznych) na temat jakości kształcenia akademickiego w czasie pandemii COVID-19, a także rekomendowanych przez nich działań na rzecz doskonalenia procesów uczenia się w sytuacji ciągłego zagrożenia epidemicznego. Głównym narzędziem w przyjętym modelu badawczym były autorskie formularze ankietowe, oparte na metodyce Servqual. Badania ankietowe przeprowadzono za pośrednictwem Internetu (kwiecień-maj 2021). Przedstawione w publikacji wyniki badań obrazują występujące luki (różnice) pomiędzy oczekiwaniami studentów i wykładowców a ocenianymi przez nich aspektami, składającymi się na jakość kształcenia akademickiego. W badaniach uczestniczyło 145 studentów, reprezentujących 12 polskich uczelni, w tym pięciu województw: dolnośląskiego, małopolskiego, opolskiego, podkarpackiego i mazowieckiego. Reprezentowali oni zarówno praktyczny, jak i ogólnoakademicki profil studiów, studia stacjonarne i niestacjonarne. W przypadku
\end{abstract}

${ }^{1}$ Beata Krystyna Detyna, Instytut Przyrodniczo-Techniczny, Państwowa Wyższa Szkoła Zawodowa im. Angelusa Silesiusa w Wałbrzychu, Polska, e-mail: beata.detyna@wp.pl, ORCID ID: https://orcid.org/0000-0002-4854-8433. 
wykładowców próbę badawczą stanowiło 81 pracowników akademickich, reprezentujących 20 polskich uczelni. Grupa ta reprezentowała dziewięć województw, w tym najliczniej: dolnośląskie, małopolskie, warmińsko-mazurskie, mazowieckie oraz śląskie. Najliczniej reprezentowaną grupą wykładowców według zajmowanego stanowiska byli: adiunkci, starsi wykładowcy, profesorowie uczelni, wykładowcy i asystenci. W publikacji przedstawiono najczęściej wskazywane przez studentów i wykładowców problemy związane z przedłużającą się pandemią COVID-19, w tym realizacją zajęć zdalnych. Zaprezentowano również rekomendowane przez respondentów sposoby udoskonalenia organizacji zajęć dydaktycznych w kontekście zagrożenia epidemicznego.

\title{
Słowa kluczowe:
}

kształcenie akademickie, jakość kształcenia, ocena jakości kształcenia, metoda Servqual, kształcenie w dobie pandemii COVID-19, kształcenie zdalne, kształcenie hybrydowe

\begin{abstract}
Understanding the opinions of students and lecturers of Polish universities on the quality of academic education during the COVID-19 pandemic, as well as their recommended activities for improvement of learning processes in the event of a constant epidemic threat was the main goal of the conducted research. The main tool in the adopted research model were proprietary questionnaire forms based on the Servqual methodology. The research results presented in the publication illustrate the gaps (differences) between the expectations of students and lecturers and the aspects assessed by them, which make up the quality of academic education. 145 students, representing 12 Polish universities participated in the research. They represented both a practical and general academic profile of studies, full-time and part-time studies. In the case of lecturers, the research sample was 81 academic staff representing 20 Polish universities. According to the position held, the most numerous group of lecturers were: assistant professors, senior lecturers, university professors, lecturers and assistants. The publication presents the problems most frequently indicated by students and lecturers related to the prolonged COVID-19 pandemic, including the implementation of distance learning. Methods of improving the organization of didactic classes in the context of the epidemic threat were also presented.
\end{abstract}

\section{Keywords:}

academic education, quality of education, assessment of the education quality, Servqual method, education in time of the COVID-19 pandemic, remote education, hybrid education 


\section{WPROWADZENIE}

Nauczanie w dobie pandemii COVID-19 stało się na przestrzeni lat 2020-2021 przyczynkiem do poszukiwania odpowiedzi na pytania dotyczące skuteczności i efektywności kształcenia akademickiego realizowanego w dużej części w formie zdalnej. Nowe realia, w których realizowane są programy studiów, stanowią inspirację dla wielu badaczy (Pokhrel, Chhetri, 2021; Lopes, McKay, 2020; Basilaia, Kvavadze, 2020; Cellary, 2020; Schleicher, 2020; Długosz, Foryś, 2020). W literaturze już dzisiaj możemy znaleźć wiele wyników badań i opracowań naukowych dotyczących identyfikowanych problemów. O wpływie dystansu społecznego na dydaktykę, w tym problemach komunikacyjnych, piszą m.in. J. Czarkowski i E. Gruszyńska (Czarkowski, 2020a; Czarkowski, 2020b; Gruszczyńska, 2020). W kontekście kształcenia akademickiego w dobie pandemii istotne są także często zmieniające się prawne uwarunkowania organizacji i prowadzenia zajęć zdalnych (Sękowski, 2020). Wyzwaniem dla studentów i wykładowców stał się przy tym rozwój umiejętności w zakresie praktycznego wykorzystywania nowych (wcześniej mało znanych) metod i narzędzi nauczania (Siemieniecka, 2020; Strzelec, 2020). Dla uczelni nowym wyzwaniem jest także konieczność pomiaru efektywności i jakości kształcenia zdalnego (Petrie, 2020; Kraśniewski, 2020). Ewaluacja jakości usług edukacyjnych jest bowiem podstawą do wprowadzenia oczekiwanych przez różne grupy interesariuszy zmian (Detyna, 2018). O opiniach studentów na temat kształcenia w czasie zagrożenia epidemicznego piszą m.in. E.J. Sintema, D. Leżański i J. Sobolewska (Sintema, 2020; Leżański, Sobolewska, 2020). Pomimo identyfikowanych wielu problemów i trudności wielu badaczy widzi w obecnej sytuacji szansę na poprawę jakości kształcenia, w tym organizacyjne uelastycznienie i wzbogacenie procesów dydaktycznych o nowe formy, metody i narzędzia (Mazur, 2021; Łaszczyk, 2020; Murphy, 2020; Piwowarska, 2020).

W kontekście opisywanych w literaturze współczesnych wyzwań autorka postawiła sobie za cel główny poznanie opinii studentów i wykładowców polskich uczelni (publicznych i niepublicznych) na temat jakości kształcenia akademickiego w czasie pandemii COVID-19 (2020-2021), a także rekomendowanych przez nich działań na rzecz doskonalenia procesów uczenia się w sytuacji ciągłego zagrożenia epidemicznego. 


\section{METODYKA BADAŃ}

Głównym narzędziem w przyjętej metodyce badawczej były autorskie formularze ankietowe, które wykorzystano do przeprowadzenia równoległych badań wśród studentów i wykładowców. Badania ankietowe przeprowadzono za pośrednictwem Internetu w okresie od 10.04.2021 r. do 10.05.2021 r. Ankiety były anonimowe i w obu przypadkach składały się z czterech podstawowych części. W pierwszych trzech częściach A-C wykorzystano koncepcję badań Servqual - umożliwiającą określenie istniejącej luki pomiędzy oczekiwaniami a ocenami poszczególnych aspektów, składających się na postrzeganą jakość kształcenia akademickiego. W części ostatniej - D - zawarto kilka pytań uzupełniających.

Metodyka Servqual umożliwiła określenie luki (różnicy) pomiędzy oczekiwaniami studentów i wykładowców a ocenianymi przez nich aspektami, składającymi się na jakość kształcenia akademickiego. Różnica między stanem faktycznym (P Perception) a oczekiwaniami (E - Expectation) stanowi tzw. rezultat nieważony Servqual (P-E). W wyniku przeprowadzonych badań otrzymano wartości liczbowe. I tak, w przypadku gdy:

- P>E (wartości są dodatnie) - oceniana jakość jest zaskakująca (powyżej oczekiwań),

- $\mathrm{P}<\mathrm{E}$ (wartości są ujemne) - oceniana jakość jest niezadowalająca,

- P=E (wartości zero) - jakość jest zadowalająca (nie występuje luka) (Detyna, 2010).

W przypadku formularza ankietowego skierowanego do studentów w części A poproszono respondentów o wskazanie (w skali od 1 do 7) swoich oczekiwań względem poszczególnych elementów analizy (aspektów). Przy tym cyfra 1 oznaczała, że element jest mało istotny, a 7 - że jest bardzo istotny. Wybrane do analizy aspekty dotyczyły pięciu wymiarów badawczych: wymiaru materialnego (I), profesjonalizmu (II), niezawodności (III), dostosowywania się do potrzeb studentów (IV) oraz empatii (V) - tab. 1.

W części B formularza poproszono respondentów o zaznaczenie (w skali od 1 do 7) swoich ocen względem poszczególnych elementów analizy (tych samych aspektów co w części A). Przy czym cyfra 1 - oznaczała najniższą ocenę, a 7 ocenę najwyższą. W części C natomiast ankietowanych poproszono o podzielenie 100\% na pięć ocenianych wymiarów - dla wskazania ich ważności. Wagi poszczególnych wymiarów posłużyły do wyznaczenia tzw. ważonych wyników Servqual. W ostatniej części formularza ankietowego (D) zwrócono się do studentów z prośbą o wskazanie najbardziej dokuczliwych problemów związanych z przedłużającą się pandemią COVID-19, w tym realizacją zajęć zdalnych. Formularz zawierał 
Tab. 1. Wymiary i elementy analizy (aspekty) podlegające ocenie przez studentów

\begin{tabular}{|c|c|}
\hline $\begin{array}{l}\text { Wymiary } \\
\text { badania }\end{array}$ & Elementy analizy \\
\hline \multirow{9}{*}{ 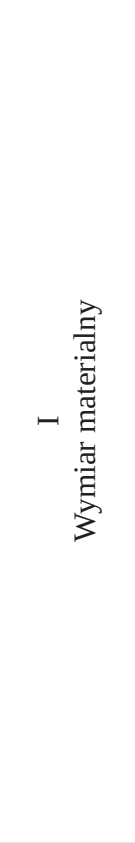 } & $\begin{array}{l}\text { 1. Dostęp do sal laboratoryjnych i pracowni podczas praktycznych zajęć, np. } \\
\text { komputerowych, specjalistycznych itp. }\end{array}$ \\
\hline & $\begin{array}{l}\text { 2. Dostęp do platform umożliwiających prowadzenie zajęć zdalnych - } \\
\text { spotkań online z możliwością widzenia się z wykładowcą }\end{array}$ \\
\hline & $\begin{array}{l}\text { 3. Dostęp do platform przeznaczonych do zamieszczania pomocy } \\
\text { dydaktycznych (plików) oraz weryfikacji efektów uczenia się (testów, } \\
\text { egzaminów) }\end{array}$ \\
\hline & $\begin{array}{l}\text { 4. Posiadanie sprzętu umożliwiającego pełne, efektywne uczestniczenie } \\
\text { w zajęciach zdalnych (np. własnych laptopów) }\end{array}$ \\
\hline & $\begin{array}{l}\text { 5. Dostęp do zasobów bibliotecznych uczelni - możliwość wypożyczenia } \\
\text { książek, skorzystania z czytelni itp. }\end{array}$ \\
\hline & $\begin{array}{l}\text { 6. Dostęp do zasobów elektronicznych biblioteki uczelnianej - możliwość } \\
\text { skorzystania z e-booków, baz danych itp. }\end{array}$ \\
\hline & $\begin{array}{l}\text { 7. Możliwość skorzystania z infrastruktury uczelni, w tym oprogramowania, } \\
\text { np. podczas pisania prac zaliczeniowych, przygotowywania projektów, prac } \\
\text { dyplomowych itp. }\end{array}$ \\
\hline & $\begin{array}{l}\text { 8. Dostęp do uczelnianego oprogramowania na własnych laptopach (pracując } \\
\text { np. w domu) }\end{array}$ \\
\hline & $\begin{array}{l}\text { 9. Dostęp do bieżących informacji na temat organizacji zajęć dydaktycznych, } \\
\text { ich form, harmonogramów itp. }\end{array}$ \\
\hline \multirow{9}{*}{ 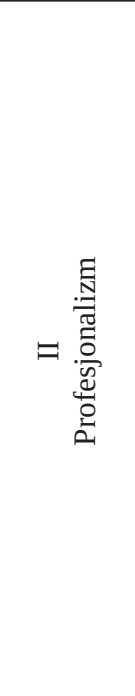 } & 10. Prezentowanie przez wykładowców dużej wiedzy merytorycznej \\
\hline & 11. Prezentowanie przez wykładowców praktycznego doświadczenia \\
\hline & $\begin{array}{l}\text { 12. Umiejętność przekazania przez wykładowców swojej wiedzy } \\
\text { i doświadczenia - sposób dzielenia się wiedzą i praktycznym doświadczeniem }\end{array}$ \\
\hline & $\begin{array}{l}\text { 13. Wykorzystywane przez wykładowców metody i narzędzia - adekwatnie do } \\
\text { celów i form prowadzonych zajęć }\end{array}$ \\
\hline & $\begin{array}{l}\text { 14. Sprawność posługiwania się przez wykładowców narzędziami do } \\
\text { zdalnego prowadzenia zajęć - wykorzystywania możliwości dostępnych } \\
\text { platform itp. }\end{array}$ \\
\hline & $\begin{array}{l}\text { 15. Umiejętność aktywizowania studentów do krytycznego myślenia } \\
\text { i zadawania pytań podczas zajęć prowadzonych online }\end{array}$ \\
\hline & $\begin{array}{l}\text { 16. Poziom przekazywanych treści przez wykładowców - ich adekwatność do } \\
\text { współczesnych trendów, koncepcji, wiedzy, potrzeb rynkowych }\end{array}$ \\
\hline & 17. Uprzejmość i kultura osobista wykładowców \\
\hline & $\begin{array}{l}\text { 18. Zdolność wykładowców do tworzenia atmosfery wzajemnego zaufania } \\
\text { i szacunku }\end{array}$ \\
\hline
\end{tabular}




\begin{tabular}{|c|c|}
\hline $\begin{array}{l}\text { Wymiary } \\
\text { badania }\end{array}$ & Elementy analizy \\
\hline \multirow{4}{*}{ 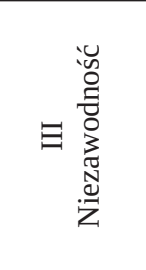 } & 19. Punktualność prowadzących zajęcia, w tym zajęcia zdalne \\
\hline & $\begin{array}{l}\text { 20. Rzetelność realizowanych zajęć dydaktycznych - zgodnie z programem } \\
\text { studiów, w tym kartami przedmiotów ECTS (sylabusami) oraz planem zajęć }\end{array}$ \\
\hline & 21. Dostępność wykładowców poza zajęciami w ramach konsultacji \\
\hline & $\begin{array}{l}\text { 22. Komunikacja z wykładowcami poza zajęciami dydaktycznymi - np. poprzez } \\
\text { pocztę mailową, dostępne platformy, system indeksu elektronicznego itp. }\end{array}$ \\
\hline \multirow{3}{*}{ 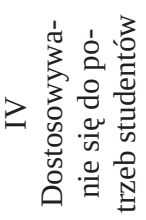 } & $\begin{array}{l}\text { 23. Uwzględnianie w procesie kształcenia akademickiego zmieniających się } \\
\text { potrzeb rynku pracy, w tym potrzeb studentów }\end{array}$ \\
\hline & $\begin{array}{l}\text { 24. Elastyczność w dostosowywaniu metod i narzędzi dydaktycznych do po- } \\
\text { trzeb i możliwości studentów }\end{array}$ \\
\hline & 25. Gotowość wykładowców do pomocy studentom, którzy tego potrzebują \\
\hline \multirow{2}{*}{ 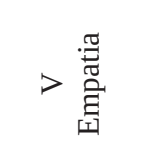 } & $\begin{array}{l}\text { 26. Indywidualne podejście do studentów - umiejętność identyfikowania } \\
\text { potrzeb studentów }\end{array}$ \\
\hline & $\begin{array}{l}\text { 27. Umiejętność wczuwania się w sytuację studenta, w tym w sytuację związaną } \\
\text { z pandemią COVID-19 }\end{array}$ \\
\hline
\end{tabular}

Źródło: opracowanie własne.

także kilka pytań z możliwością zamieszczenia przez respondentów opisowych (otwartych) odpowiedzi:

- Czy w przypadku możliwego powrotu na uczelnię i prowadzenia wszystkich zajęć dydaktycznych w sposób stacjonarny (tradycyjny) jest Pan/Pani za tym, aby część zajęć teoretycznych (wykładów) prowadzić w formie e-learningu?

- W jaki sposób uczelnia, na której studiujesz, mogłaby udoskonalić organizację zajęć dydaktycznych prowadzonych stacjonarnie (w siedzibie uczelni), w kontekście zagrożenia epidemicznego COVID-19? Proszę podać proponowane rozwiqzania.

- W jaki sposób uczelnia, na której studiujesz, mogłaby udoskonalić organizację zajęć dydaktycznych - prowadzonych zdalnie (online), w kontekście zagrożenia epidemicznego COVID-19? Proszę podać proponowane rozwiq̨zania.

Próbę badawczą stanowiło 145 studentów, reprezentujących 12 polskich uczelni (96,50\% z uczelni publicznych i 3,50\% z prywatnych). Reprezentowali oni pięć województw: dolnośląskie (45,83\%), małopolskie (31,94\%), opolskie (15,97\%), podkarpackie (3,47\%) oraz mazowieckie (2,78\%) - rys. 1 . 


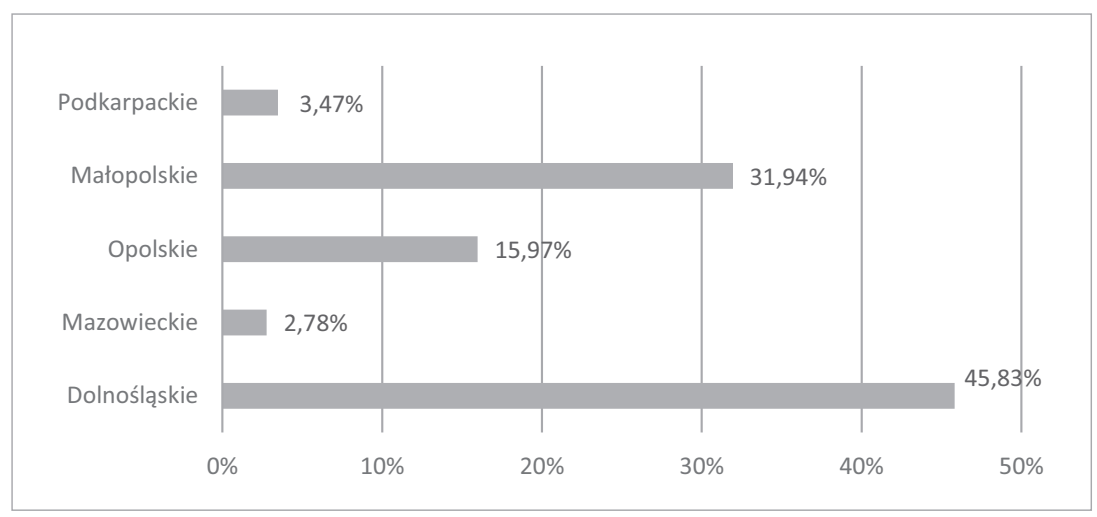

Rys. 1. Struktura uczestniczących w badaniach studentów według województw Źródło: opracowanie własne.

Studenci reprezentowali profil praktyczny (53,80\%) i ogólnoakademicki (46,20\%). Próbę badawczą stanowiło 84\% studentów stacjonarnych i 16\% niestacjonarnych. Przy tym najliczniejszą grupę stanowili studenci studiów pierwszego stopnia - inżynierskich (43,36\%) oraz studiów drugiego stopnia (30,07\%). Studenci studiów licencjackich stanowili 25,87\%, a szkół doktorskich (0,70\%). Strukturę respondentów według poziomu studiów prezentuje rys. 2. Studenci I roku studiów stanowili 27,30\%, II roku - 23,10\%, III - 31,50\%, IV - 9,10\%, V - 7,70\%, a VI - 1,40\%.

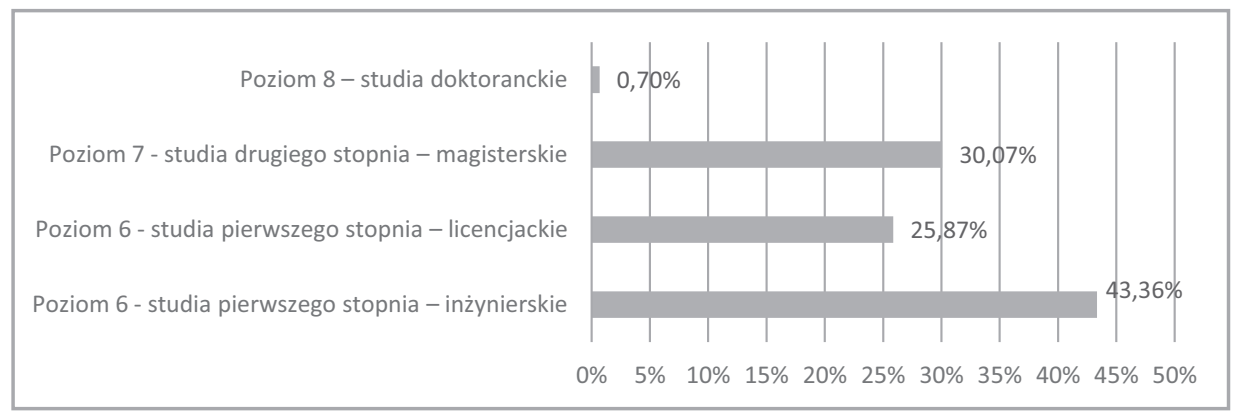

Rys. 2. Struktura uczestniczących w badaniach studentów według poziomu studiów Źródło: opracowanie własne.

W przypadku formularza ankietowego przeznaczonego dla wykładowców przyjęto inny niż dla studentów zestaw wymiarów i elementów podlegających analizie - tab. 2. Przyjęte skale dotyczące oczekiwań i ocen poszczególnych aspek- 
tów były jednakowe (od 1 do 7) - analogicznie jak w przypadku formularza dla studentów. Wybrane do analizy aspekty dotyczyły pięciu wymiarów badawczych: wymiaru materialnego (I), wymiaru organizacyjnego (II), metod i narzędzi (III), komunikacji (IV) oraz postawy studentów (V).

\section{Tab. 2. Wymiary i elementy analizy (aspekty) podlegające ocenie przez wykładowców}

\begin{tabular}{|c|c|}
\hline $\begin{array}{l}\text { Wymiary } \\
\text { badania }\end{array}$ & Elementy analizy \\
\hline \multirow{8}{*}{ 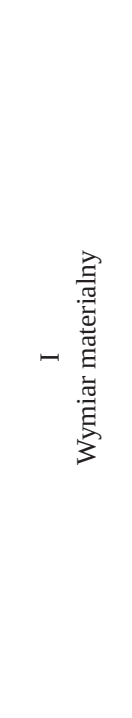 } & $\begin{array}{l}\text { 1. Dostęp do sal laboratoryjnych i pracowni podczas praktycznych zajęć, np. kom- } \\
\text { puterowych, specjalistycznych itp. }\end{array}$ \\
\hline & $\begin{array}{l}\text { 2. Dostęp do platform umożliwiających prowadzenie zajęć zdalnych - spotkań } \\
\text { online z możliwością widzenia się ze studentami }\end{array}$ \\
\hline & $\begin{array}{l}\text { 3. Dostęp do platform przeznaczonych do zamieszczania pomocy dydaktycznych } \\
\text { (plików) oraz weryfikacji efektów uczenia się (testów, egzaminów) }\end{array}$ \\
\hline & $\begin{array}{l}\text { 4. Dysponowanie sprzętem umożliwiającym pełne i efektywne przeprowadzenie } \\
\text { zajęć zdalnych (np. własnych laptopów itd.) }\end{array}$ \\
\hline & $\begin{array}{l}\text { 5. Dostęp do zasobów bibliotecznych uczelni - możliwość wypożyczenia książek, } \\
\text { skorzystania z czytelni itp. }\end{array}$ \\
\hline & $\begin{array}{l}\text { 6. Dostęp do zasobów elektronicznych biblioteki uczelnianej - możliwość skorzy- } \\
\text { stania z e-booków, baz danych itp. }\end{array}$ \\
\hline & $\begin{array}{l}\text { 7. Możliwość skorzystania z infrastruktury uczelni w jej siedzibie, w tym z oprogra- } \\
\text { mowania, np. podczas przygotowywania się do zajęć, realizacji badań naukowych, } \\
\text { pisania publikacji itp. }\end{array}$ \\
\hline & $\begin{array}{l}\text { 8. Dostęp do uczelnianego oprogramowania na własnych laptopach - wykorzysty- } \\
\text { wanego podczas prowadzenia zajęć zdalnych }\end{array}$ \\
\hline \multirow{4}{*}{ 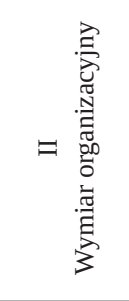 } & $\begin{array}{l}\text { 9. Adekwatność przyjętych w uczelni rozwiązań organizacyjnych w zakresie prowa- } \\
\text { dzenia zajęć dydaktycznych do występującej sytuacji epidemicznej }\end{array}$ \\
\hline & 10. Plan zajęć zdalnych z właściwym rozkładem form i godzin zajęć \\
\hline & $\begin{array}{l}\text { 11. Dostęp do bieżących informacji na temat organizacji zajęć dydaktycznych, } \\
\text { harmonogramów, wprowadzanych zmian itp. }\end{array}$ \\
\hline & $\begin{array}{l}\text { 12. Organizacja zajęć stacjonarnych np. w pracowniach komputerowych i specjali- } \\
\text { stycznych z zachowaniem bezpieczeństwa epidemicznego }\end{array}$ \\
\hline \multirow{4}{*}{ 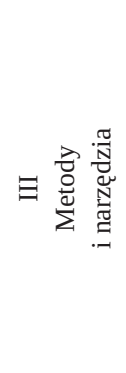 } & $\begin{array}{l}\text { 13. Możliwości dostępnych platform do e-learningu w zakresie wykorzystywania } \\
\text { różnych metod i narzędzi - adekwatnie do celów przedmiotowych i potrzeb studentów }\end{array}$ \\
\hline & $\begin{array}{l}\text { 14. Możliwość dostępnych platform do e-learningu w zakresie obiektywnej } \\
\text { weryfikacji efektów uczenia się studentów - w ramach prac indywidualnych i zespo- } \\
\text { łowych, realizacji zadań, zaliczeń, egzaminów itp. }\end{array}$ \\
\hline & $\begin{array}{l}\text { 15. Możliwość uczestniczenia wykładowców w szkoleniach rozwijających umiejęt- } \\
\text { ności praktycznego wykorzystania nowych technologii w procesie dydaktycznym }\end{array}$ \\
\hline & $\begin{array}{l}\text { 16. Oferowanie wykładowcom szkoleń w zakresie poznawania nowych metod } \\
\text { i narzędzi dydaktycznych }\end{array}$ \\
\hline
\end{tabular}




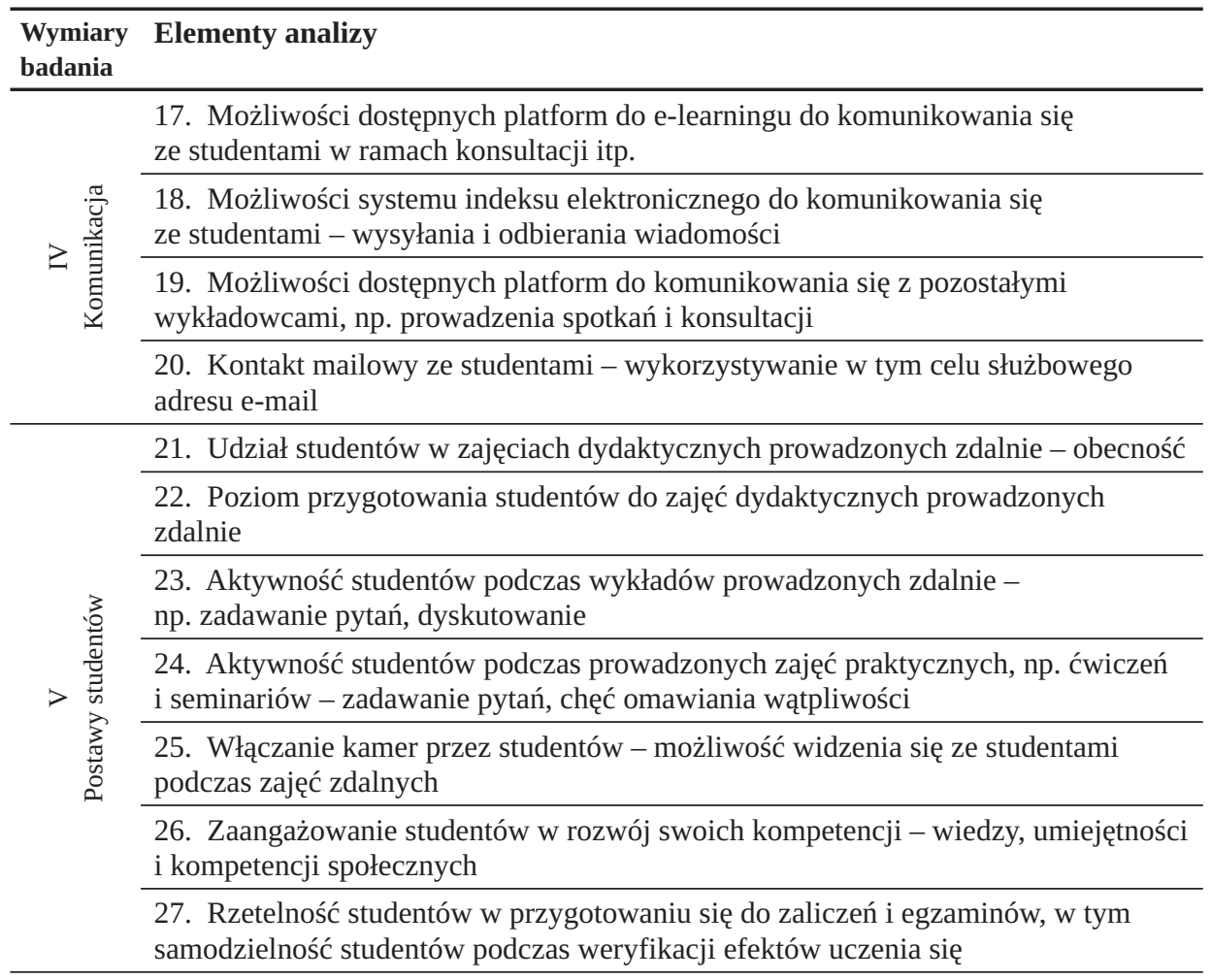

Źródło: opracowanie własne.

W części B, analogicznie jak studentów, poproszono wykładowców o zaznaczenie w skali od 1 do 7 swoich ocen względem poszczególnych elementów analizy (tych samych co w części A) - gdzie cyfra 1 oznaczała najniższą ocenę, a 7 - ocenę najwyższą. W części C wykładowcy mieli podzielić 100\% na pięć ocenianych wymiarów - wskazując ich ważność. Proszono ich także o wskazanie najbardziej dokuczliwych problemów związanych z przedłużającą się pandemią COVID-19. Pytania otwarte w części D formularza były tożsame z zawartymi w formularzu dla studentów.

W przypadku wykładowców próbę badawczą stanowiło 81 pracowników akademickich, reprezentujących 20 uczelni (90\% publicznych i 10\% prywatnych). Grupa ta reprezentowała dziewięć województw, w tym najliczniej: dolnośląskie (41,03\%), małopolskie (21,79\%), warmińsko-mazurskie (20,51\%), mazowieckie (5,15\%) oraz śląskie (5,13\%) - rys. 3.

Najliczniej reprezentowaną grupą wykładowców według zajmowanego stanowiska byli: adiunkci (40,26\%), starsi wykładowcy (19,48\%), profesorowie uczelni 


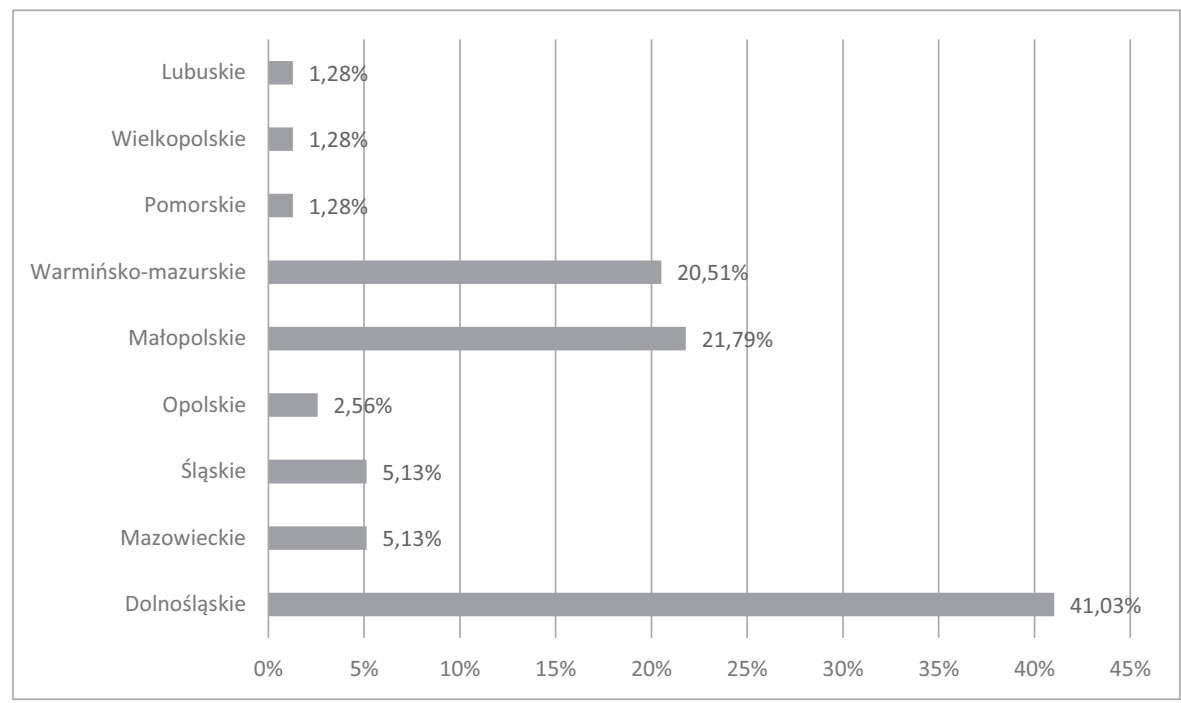

Rys. 3. Struktura uczestniczących w badaniach wykładowców według województw Źródło: opracowanie własne.

(14,29\%), wykładowcy (9,09\%) oraz asystenci (9,09\%). Profesorowie stanowili 3,90\%, a lektorzy i instruktorzy łącznie 3,90\% - rys. 4 .

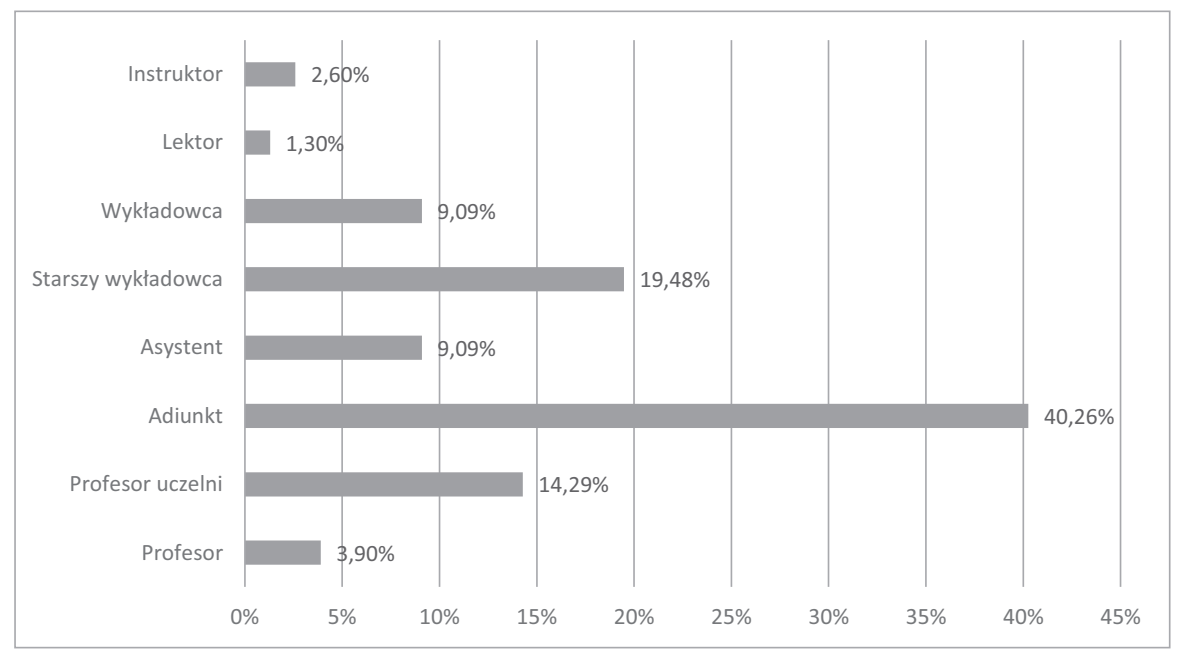

Rys. 4. Struktura uczestniczących w badaniach wykładowców według stanowisk Źródło: opracowanie własne. 
Strukturę uczestniczących w badaniach wykładowców ze względu na staż pracy przedstawiono na rys. 5. Dominującymi w próbie badawczej wykładowcami były osoby posiadające staż pracy dłuższy niż 30 lat (22,78\%), następnie osoby pracujące krócej niż 5 lat (20,25\%), pracujące od 6 do 10 lat (13,92\%), od 16 do 20 lat (13,92\%), od 11 do 15 lat (12,66\%) oraz od 21 do 25 lat $(11,39 \%)$ obrazuje to rys. 5 .

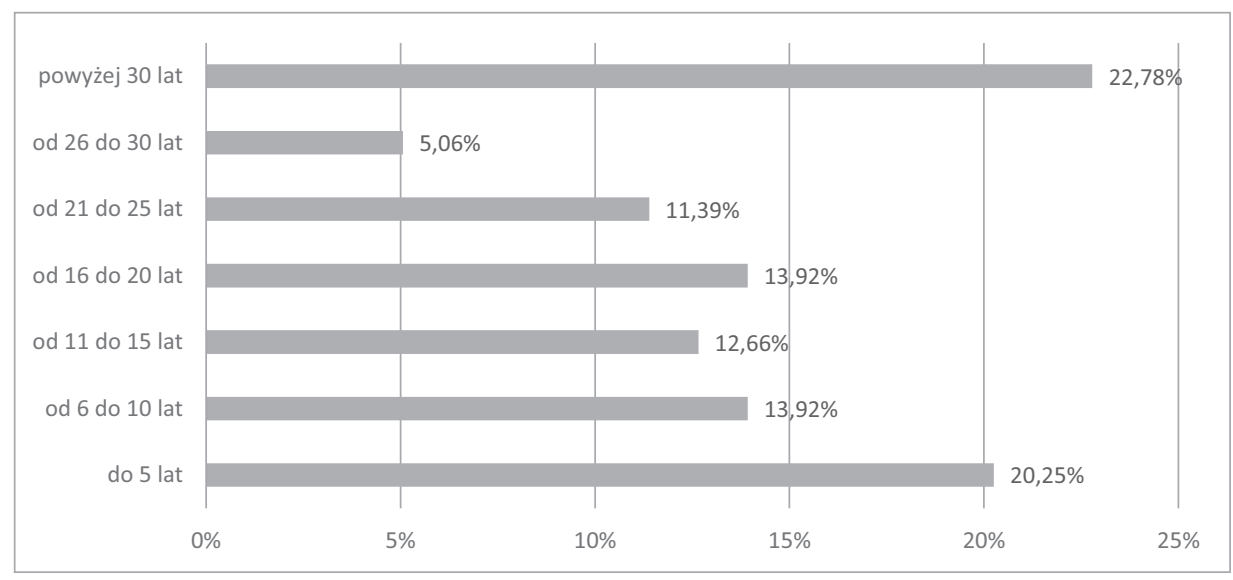

Rys. 5. Struktura uczestniczących w badaniach wykładowców według stażu pracy Źródło: opracowanie własne.

\section{WYNIKI BADANIA SERVQUAL - PERSPEKTYWA STUDENTÓW}

W wyniku przeprowadzonych badań poznano opinię studentów na temat ważności poszczególnych wymiarów, które podlegały ocenie. Średnie „wagi” wskazane przez respondentów to dla:

- wymiaru materialnego (I) - 21,63\%,

- profesjonalizmu (II) - 26,99\%,

- niezawodności (III) - 18,16\%,

- dostosowywania się do potrzeb studentów (IV) - 17,86\%,

- empatii (V) - 15,92\%.

Najważniejsze dla badanych studentów są aspekty dotyczące profesjonalizmu oraz wymiaru materialnego. Nieco niższe wartości dla „wag” poszczególnych obszarów wskazano dla: niezawodności, dostosowywania się do potrzeb studentów oraz empatii. Udziały procentowe dotyczące ważności poszczególnych obszarów badawczych pozwoliły na przedstawienie wyników w postaci tzw. średnich 
rezultatów ważonych Servqual - rys. 7. Do ich obliczenia wykorzystano wyniki tzw. średnich nieważonych rezultatów Servqual (rys. 6) - mnożąc je przez „wagi” poszczególnych wymiarów.

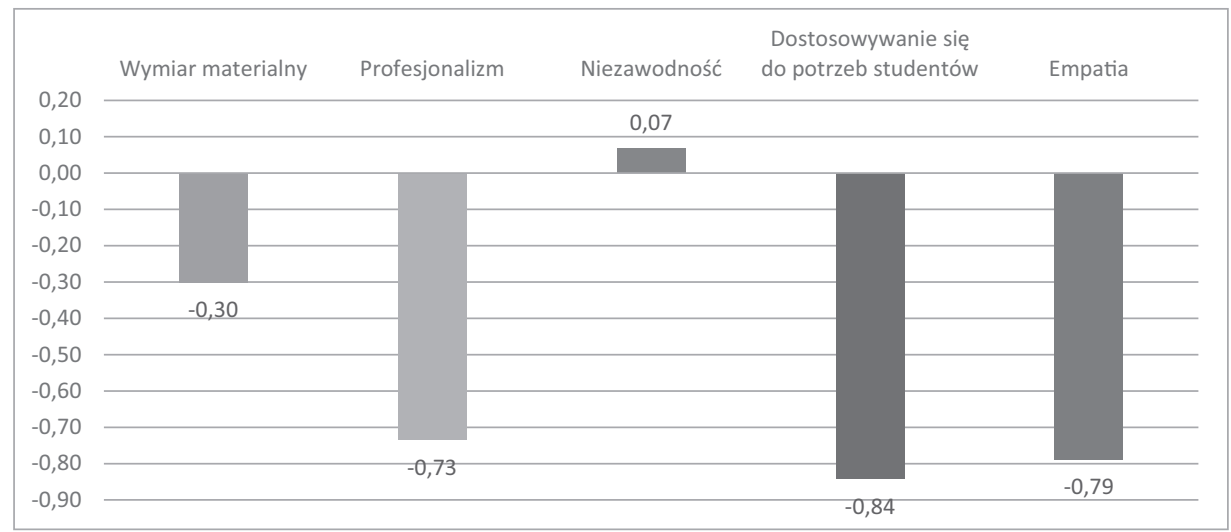

Rys. 6. Średnie nieważone rezultaty Servqual dla pięciu badanych wymiarów - opinie studentów Źródło: opracowanie własne.

Interpretując wyniki badań, należy odnieść się do średnich ważonych rezultatów Servqual, ponieważ uwzględniają one „wagę” każdego wymiaru (badanego obszaru) dla respondentów. Różnice pomiędzy wynikami zaprezentowanymi na rys. 6 i rys. 7 są relatywnie małe, ponieważ średnie „wagi” dla badanych obszarów według studentów są do siebie zbliżone (największa różnica dotyczy postrzegania wymiaru profesjonalnego (ok. 27\%) i empatii (ok. 16\%).

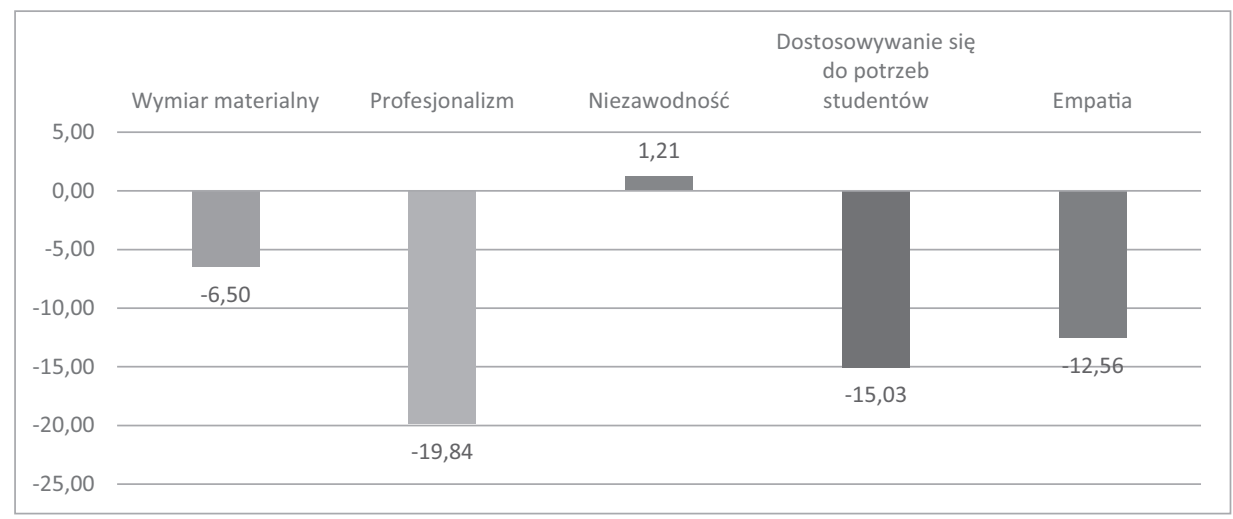

Rys. 7. Średnie rezultaty ważone Servqual dla pięciu badanych wymiarów - opinie studentów Źródło: opracowanie własne. 
W jednym przypadku odnotowano jakość na poziomie zaskakującym (P>E), co dowodzi, że oceny badanych studentów były nieco wyższe niż ich oczekiwania - dotyczy to wymiaru niezawodności $(+1,21)$. Największe różnice pomiędzy ocenami a oczekiwaniami odnotowano w przypadku profesjonalizmu $(-19,84)$, dostosowywania się do potrzeb studentów $(-15,03)$ oraz empatii $(-12,56)$. Relatywnie mała „luka” występuje w przypadku wymiaru materialnego $(-6,50)$.

Dokładne wnioski dotyczące oceny kształcenia akademickiego w warunkach zagrożenia epidemicznego COVID-19 można wyciągać po analizie tzw. średnich nieważonych rezultatów Servqual dla ocenianych (wszystkich 27 aspektów) rys. 8.

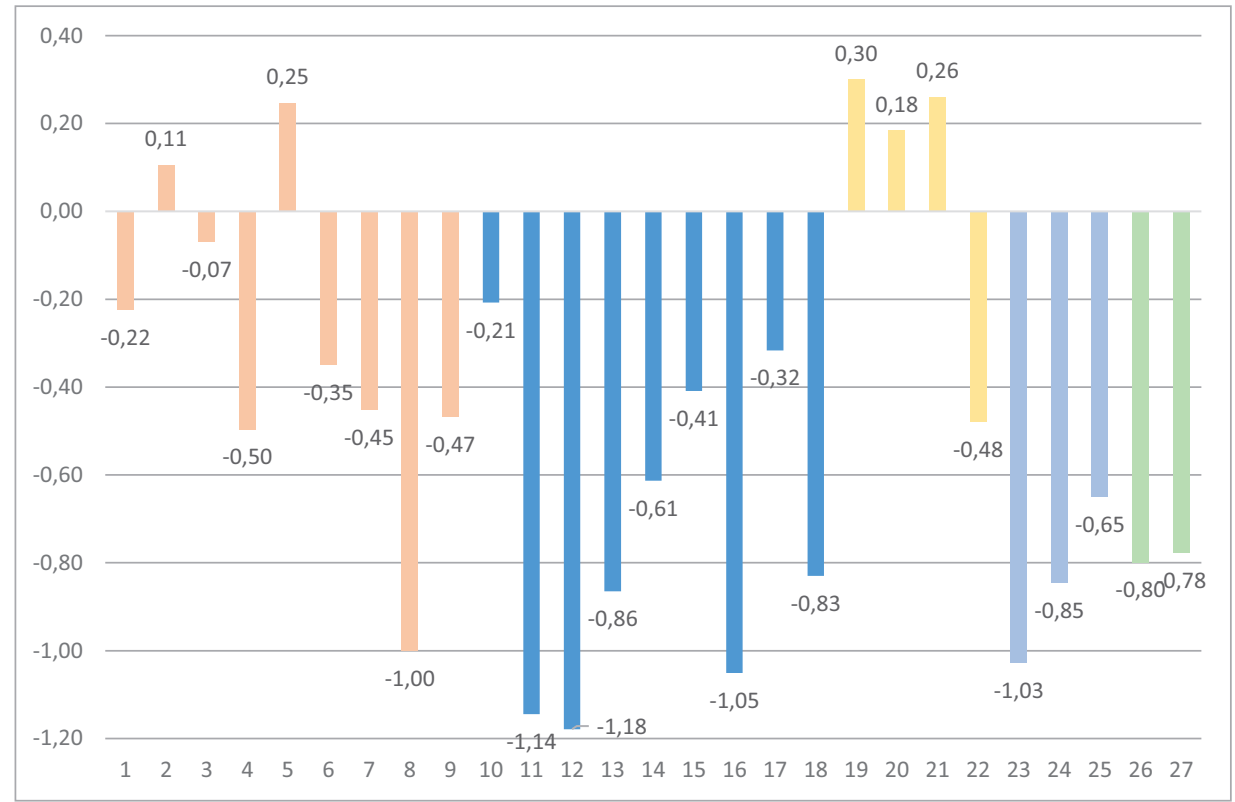

Rys. 8. Średnie nieważone rezultaty Servqual dla ocenianych aspektów - opinie studentów Źródło: opracowanie własne.

Szczegółowo analizując wyniki zaprezentowane na rys. 8, można wskazać dwa elementy oceny w ramach wymiaru materialnego oraz trzy w ramach ocenianej niezawodności, które zostały ocenione powyżej oczekiwań respondentów. Zaskakująco wysokie oceny odnotowano:

- w ramach wymiaru materialnego za:

- dostęp do platform umożliwiających prowadzenie zajęć zdalnych spotkań online z możliwością widzenia się ze studentami (2), 
- dostęp do zasobów bibliotecznych uczelni - możliwość wypożyczenia książek, skorzystania z czytelni itp.;

- w ramach niezawodności za:

- punktualność prowadzących zajęcia, w tym zajęcia zdalne (19),

- rzetelność realizowanych zajęć dydaktycznych - zgodnie z programem studiów, w tym kartami przedmiotów ECTS (sylabusami) oraz planem zajęć (20),

- dostępność wykładowców poza zajęciami w ramach konsultacji (21) patrz tab. 1.

Przyjęta przez autorkę metodyka badawcza pozwala na wskazanie tych elementów, dla których odnotowano największe „luki” pomiędzy oczekiwaniami studentów a oceną jakości kształcenia akademickiego w dobie pandemii COVID-19. Największe różnice, które widać na rys. 8, powinny stać się przesłanką do wprowadzenia w uczelniach działań doskonalących. Należą do nich przede wszystkim:

- w wymiarze materialnym:

- dostęp do uczelnianego oprogramowania na własnych laptopach, pracując np. w domu (8) - wynik -1,00;

- w wymiarze profesjonalizmu:

- umiejętność przekazania przez wykładowców swojej wiedzy i doświadczenia - sposób dzielenia się wiedzą i praktycznym doświadczeniem (12) - wynik -1,18,

- prezentowanie przez wykładowców praktycznego doświadczenia (11) - wynik -1,14,

- poziom przekazywanych treści przez wykładowców - ich adekwatność do współczesnych trendów, koncepcji, wiedzy, potrzeb rynkowych(16)-wynik $-1,05$,

- wykorzystywane przez wykładowców metody i narzędzia - adekwatnie do celów i form prowadzonych zajęć (13) - wynik -0,86,

- zdolność wykładowców do tworzenia atmosfery wzajemnego zaufania i szacunku (18) - wynik -0,83;

- w wymiarze dostosowywania się do potrzeb studentów:

- uwzględnianie w procesie kształcenia akademickiego zmieniających się potrzeb rynku pracy, w tym potrzeb studentów (23) - wynik -1,03,

- elastyczność w dostosowywaniu metod i narzędzi dydaktycznych do potrzeb i możliwości studentów (24) - wynik -0,85.

Najlepsze wyniki odnotowano w wymiarze niezawodności, a zidentyfikowana różnica dotycząca dostępności wykładowców poza zajęciami w ramach konsul- 
tacji (aspekt 22) jest relatywnie bardzo mała $(-0,48)$. Relatywnie małe różnice odnotowano także w obszarze empatii.

\section{WYNIKI BADANIA SERVQUAL - PERSPEKTYWA WYKŁADOWCÓW}

W wyniku przeprowadzonych badań poznano opinię wykładowców na temat ważności poszczególnych wymiarów, które podlegały ocenie. Średnie „wagi” wskazane przez respondentów to dla:

- wymiaru materialnego (I) - 17,61\%,

- wymiaru organizacyjnego (II) - 17,16\%,

- metod i narzędzi (III) - 19,20\%,

- komunikacji (IV) - 20,23\%,

- postawy studentów (V) - 26,59\%.

Najważniejszym dla badanych wykładowców są aspekty dotyczące postaw studentów oraz komunikacji. Nieco niższe wartości dla „wag” poszczególnych obszarów wskazano dla: metod i narzędzi, wymiaru materialnego oraz organizacyjnego. Dane dotyczące „wag” poszczególnych obszarów pozwoliły na przedstawienie wyników w postaci tzw. średnich rezultatów ważonych Servqual według badanych wykładowców - rys. 10. Do ich obliczenia wykorzystano wyniki tzw. średnich nieważonych rezultatów Servqual (rys. 9) - analogicznie jak w przypadku badania dotyczącego studentów.

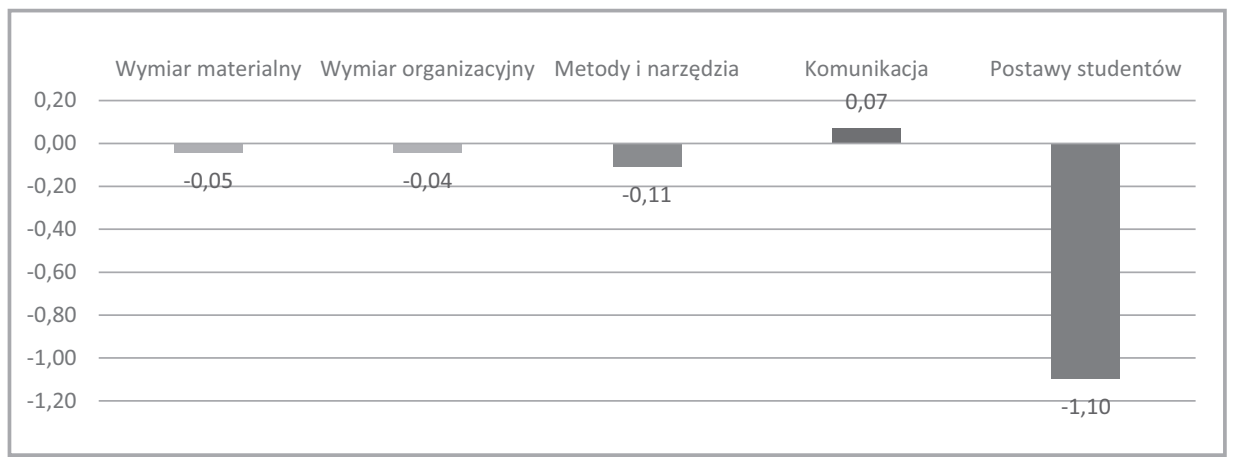

Rys. 9. Średnie nieważone rezultaty Servqual dla pięciu badanych wymiarów - opinie wykładowców Źródło: opracowanie własne.

Różnice pomiędzy wynikami zaprezentowanymi na rys. 9 i rys. 10 są relatywnie małe, ponieważ średnie „wagi” dla badanych obszarów według wykładowców 
są do siebie zbliżone - największa różnica dotyczy postrzegania ważności postaw studentów (ok. 27\%) i wymiaru organizacyjnego (ok. 17\%).

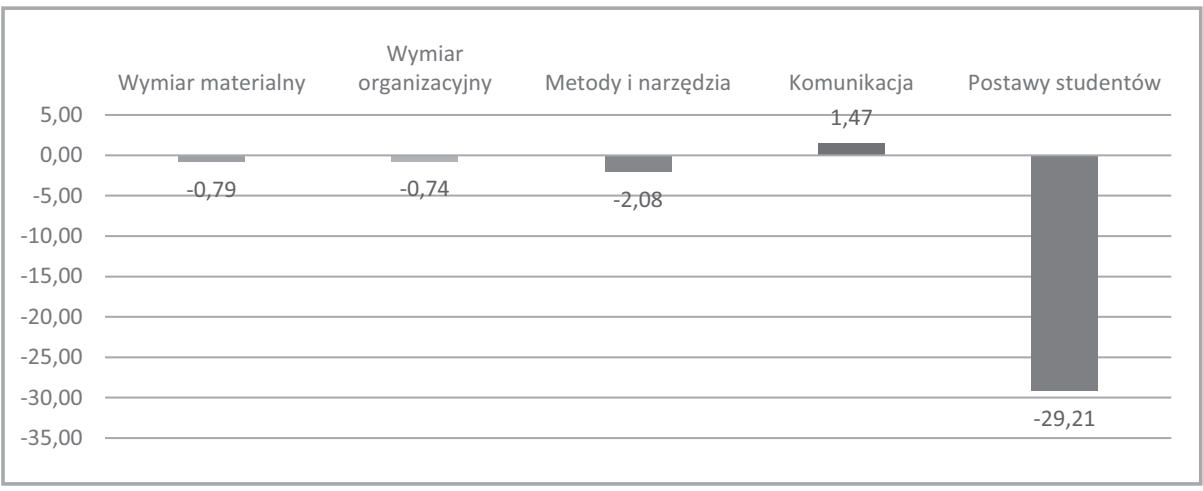

Rys. 10. Średnie rezultaty ważone Servqual dla pięciu badanych wymiarów - opinie wykładowców Źródło: opracowanie własne.

W jednym przypadku odnotowano jakość na poziomie zaskakującym (P>E), co dowodzi, że oceny badanych wykładowców były nieco wyższe niż ich oczekiwania - dotyczy to wymiaru komunikacja $(+1,47)$. Największe różnice pomiędzy ocenami a oczekiwaniami odnotowano w przypadku postaw studentów $(-29,21)$. W przypadku pozostałych obszarów zidentyfikowane „luki” są relatywnie bardzo małe - wartości świadczą o tym, że jakość jest bliska zadowalającej.

Analiza tzw. średnich nieważonych rezultatów Servqual dla ocenianych (wszystkich 27 aspektów) pozwoliła na wskazanie tych aspektów, które zdaniem respondentów wymagają zdecydowanej poprawy - rys. 11.

Należą do nich przede wszystkim elementy dotyczące postaw studentów. W tym obszarze wszystkie aspekty zostały ocenione przez wykładowców poniżej ich oczekiwań. Największe „luki” dotyczą:

- poziomu przygotowania studentów do zajęć dydaktycznych prowadzonych zdalnie (25) - wynik -1,48,

- aktywności studentów podczas wykładów prowadzonych zdalnie - np. zadawanie pytań, dyskutowanie (23) - wynik -1,34,

- rzetelności studentów w przygotowaniu się do zaliczeń i egzaminów, w tym samodzielności studentów podczas weryfikacji efektów uczenia się (27) wynik $-1,21$,

- zaangażowania studentów w rozwój swoich kompetencji - wiedzy, umiejętności i kompetencji społecznych (26) - wynik -1,20, 


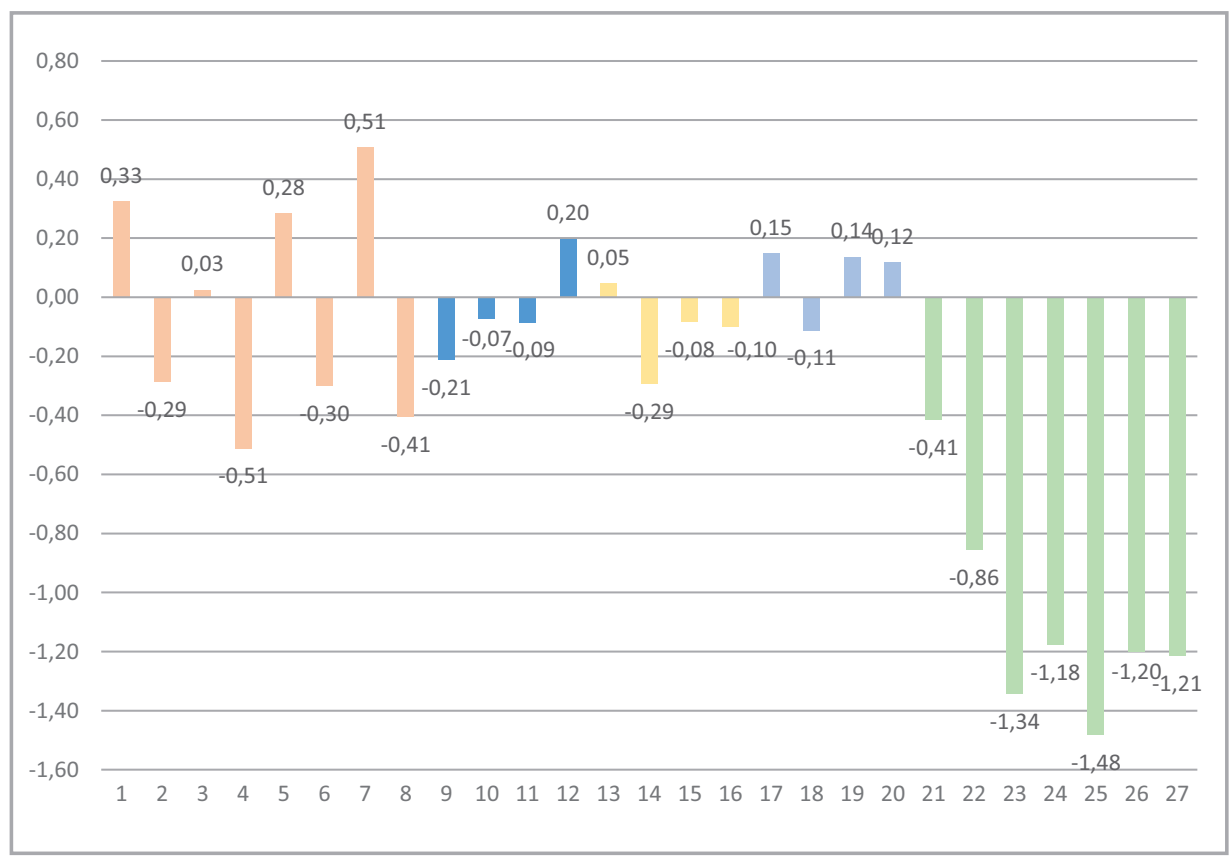

Rys. 11. Średnie nieważone rezultaty Servqual dla ocenianych aspektów - opinie wykładowców Źródło: opracowanie własne.

- aktywności studentów podczas prowadzonych zajęć praktycznych, np. ćwiczeń i seminariów - zadawanie pytań, chęć omawiania wątpliwości (24) - wynik -1,18,

- poziomu przygotowania studentów do zajęć dydaktycznych prowadzonych zdalnie (22) - wynik -0,86.

W pozostałych ocenianych wymiarach zdiagnozowane różnice pomiędzy oczekiwaniami a ocenami były relatywnie małe. W przypadku siedmiu aspektów wyniki P-E były dodatnie, co świadczy o ich zaskakująco wysokiej ocenie - rys. 11 . Najlepiej oceniono:

- możliwość skorzystania z infrastruktury uczelni w jej siedzibie, w tym z oprogramowania, np. podczas przygotowywania się do zajęć, realizacji badań naukowych, pisania publikacji itp. (7) - wynik +0,51,

- dostęp do sal laboratoryjnych i pracowni podczas praktycznych zajęć np. komputerowych, specjalistycznych itp. (1) - wynik +0,33,

- dostęp do zasobów bibliotecznych uczelni - możliwość wypożyczenia książek, skorzystania z czytelni itp. (5) - wynik +0,28, 
- organizację zajęć stacjonarnych np. w pracowniach komputerowych i specjalistycznych z zachowaniem bezpieczeństwa epidemicznego (12) - wynik $+0,20$.

\section{WSKAZYWANE PRZEZ STUDENTÓW I WYKŁADOWCÓW PROBLEMY I PROPOZYCJE DZIAŁAŃ DOSKONALĄCYCH}

Przyjęta przez autorkę metodyka badawcza pozwoliła na zebranie informacji na temat najczęściej wskazywanych przez studentów i wykładowców problemów związanych z przedłużającą się pandemią COVID-19, w tym realizacją zajęć zdalnych. Uczestniczący w badaniach studenci wskazywali na następujące problemy:

- zbyt duża liczba godzin spędzonych w jednym dniu przed komputerem $69,4 \%$,

- brak bezpośredniego kontaktu z koleżankami i kolegami z roku/grupy $63,2 \%$,

- zbyt krótkie przerwy pomiędzy poszczególnymi zajęciami zdalnymi - mało czasu na odpoczynek od komputera - 54,9\%,

- problemy z Internetem - 54,2\%,

- obniżony nastrój - 46,5\%,

- znacznie utrudniona współpraca podczas realizacji zadań i projektów zespołowych - 37,5\%,

- problemy techniczne z wykorzystaniem udostępnionych przez uczelnię platform - 36,8\%,

- silny stres - 31,9\%,

- rozdrażnienie i nerwowość - 31,3\%,

- trudności komunikacyjne z wykładowcą poza zajęciami dydaktycznymi $-29,9 \%$,

- problemy techniczne związane z posiadanym sprzętem do nauki zdalnej $-29,2 \%$,

- przewlekłe napięcie - 29,2\%,

- problemy ze snem - 29,2\%,

- niepokój - 25,0\%

- smutek - 20,8\%,

- lęk - 17,4\%,

- depresja - 11,8\%,

- agresja - 9\%,

- brak własnego laptopa - 4,2\%. 
Wśród wskazanych przez wykładowców najbardziej dokuczliwych problemów związanych z przedłużającą się pandemią COVID-19, w tym realizacją zajęć zdalnych, znalazły się:

- brak bezpośredniego kontaktu ze studentami podczas zajęć dydaktycznych - 82,5\%,

- zbyt duża liczba godzin spędzonych w jednym dniu przed komputerem - 52,5\%,

- brak bezpośredniego kontaktu z pracownikami uczelni - 41,3\%,

- problemy z Internetem - 33,8\%,

- trudności komunikacyjne ze studentami poza zajęciami dydaktycznymi-32,5\%,

- zbyt krótkie przerwy pomiędzy poszczególnymi zajęciami zdalnymi - mało czasu na odpoczynek od komputera - 27,5\%,

- obniżony nastrój - 23,8\%,

- problemy techniczne związane z posiadanym sprzętem, wykorzystywanym do prowadzenia zajęć zdalnych - 21,3\%,

- znacznie utrudniona współpraca podczas realizacji zespołowych badań naukowych i projektów - 20\%,

- problemy techniczne z wykorzystaniem udostępnionych przez uczelnię platform $-16,3 \%$,

- rozdrażnienie i nerwowość - 13,8\%,

- niepokój-13,8\%,

- problemy ze snem - 12,5\%,

- przewlekłe napięcie - 11,3\%,

- smutek - 8,8\%,

- silny stres $-6,3 \%$,

- depresja-6,3\%.

Gdy porówna się te wyniki, wyraźnie widać, że uczestniczący w badaniach studenci maja zdecydowanie więcej problemów, zarówno natury technicznej, organizacyjnej, jak i emocjonalnej. Dla badanych studentów największym problemem jest zbyt duża liczba godzin spędzonych w jednym dniu przed komputerem (69,4\%), brak bezpośredniego kontaktu z koleżankami i kolegami (63,2\%) oraz zbyt krótkie przerwy pomiędzy poszczególnymi zajęciami zdalnymi (54,9\%). Dla wykładowców największy problem stanowi brak bezpośredniego kontaktu ze studentami podczas zajęć dydaktycznych (82,5\%), zbyt duża liczba godzin spędzonych w jednym dniu przed komputerem (52,5\%), a także brak bezpośredniego kontaktu z pracownikami uczelni (41,3\%).

Respondenci wskazali wiele sposobów na udoskonalenie zajęć dydaktycznych prowadzonych zarówno stacjonarnie, jak i zdalnie. Propozycje studentów i wykładowców w kontekście występującego ciągle zagrożenia epidemicznego COVID-19 przedstawiono w tab. 3. 
Tab. 3. Sposoby udoskonalenia organizacji zajęć dydaktycznych w kontekście zagrożenia epidemicznego COVID-19 - propozycje studentów i wykładowców

\section{Sposoby udoskonalenia organizacji zajęć dydaktycznych prowadzonych stacjonarnie} (w siedzibie uczelni) - w kontekście zagrożenia epidemicznego COVID-19

\begin{tabular}{|c|c|}
\hline Propozycje studentów & Propozycje wykładowców \\
\hline $\begin{array}{l}\text { - Zajęcia hybrydowe - ćwiczenia odbywają- } \\
\text { ce się na uczelni, wykłady zdalnie; } \\
\text { - Organizacja zajęć dydaktycznych w mniej- } \\
\text { szych grupach; } \\
\text { - W cieplejsze dni można przenieść wy- } \\
\text { brane zajęcia na zewnątrz - przygotować } \\
\text { w tym celu odpowiednią infrastrukturę } \\
\text { (wystarczyłyby miejsca do siedzenia oraz } \\
\text { zadaszenie w razie deszczu); } \\
\text { - Większe wykorzystanie dużych sal } \\
\text { wykładowych, aby można było zachować } \\
\text { dystans; } \\
\text { - Wprowadzenie techniki Pomodoro na } \\
\text { wykładach; } \\
\text { - System zmianowy zajęć - np. studenci } \\
\text { podzieleni na trzy zmiany nauczania - jed- } \\
\text { ni od rana do południa, drudzy od południa } \\
\text { do popołudnia, a trzeci od popołudnia do } \\
\text { wieczora; } \\
\text { - Pilnowanie, aby osoby siedziały w odpo- } \\
\text { wiedniej odległości od siebie (ok. 1,5 m); } \\
\text { - Możliwie jak najmniejszy kontakt między } \\
\text { studentami z różnych roczników i kierun- } \\
\text { ków; } \\
\text { - Zajęcia, które muszą być przeprowadzone } \\
\text { na uczelni, mogłyby odbywać się w spo- } \\
\text { sób blokowy - tak aby czas zwiększonych } \\
\text { kontaktów z innymi osobami ograniczyć } \\
\text { do np. miesiąca czy dwóch, a nie rozkła- } \\
\text { dać je na cały semestr (niektóre zajęcia są } \\
\text { realizowane relatywnie rzadko - np. te dla } \\
\text { epidemiczne. } \\
\text { studentów niestacjonarnych); } \\
\text { - Minimalizowanie kontaktów na terenie } \\
\text { uczelni przez odpowiednie dostosowanie } \\
\text { planu zajęć; } \\
\text { - Stały skład grup ćwiczeniowych; } \\
\text { - Więcej quizów i tematów praktycznych; } \\
\text { - Więcej zajęć praktycznych, w tym spotkań } \\
\text { z przedstawicielami danej branży; } \\
\text { - Zajęcia prowadzone np. na programie } \\
\text { - }\end{array}$ & $\begin{array}{l}\text { - Zajęcia hybrydowe - łączenie możliwości } \\
\text { nauki stacjonarne i zdalnej; } \\
\text { - Zajęcia z grupami o mniejszej liczebności; } \\
\text { - Korzystanie z narzędzi „chmury” do } \\
\text { nagrywania wykładów, udostępniania ich, } \\
\text { przekazywania innych materiałów, zapisy- } \\
\text { wania prac w trakcie korekt itp.; } \\
\text { - Warto zachować formułę zajęć online } \\
\text { tam, gdzie kontakt bezpośredni nie jest } \\
\text { konieczny na każdych zajęciach; } \\
\text { - Stosowanie hybrydowej formuły na wy- } \\
\text { kładach i seminariach dyplomowych - np. } \\
\text { 50\% zajęć stacjonarnych, a 50\% zdalnych; } \\
\text { - Zajęcia warsztatowe stacjonarnie grupach } \\
\text { zapewniających bezpieczeństwo (np. } \\
\text { dystans); } \\
\text { - Zachowanie odległości pomiędzy studen- } \\
\text { tami, min. 1,5 m; } \\
\text { - Konieczność rozbudowy infrastruktury } \\
\text { laboratoryjnej; } \\
\text { - Dostępny dla wykładowców system } \\
\text { informacyjny do weryfikacji informacji na } \\
\text { temat liczebności grup itp. } \\
\text { - Dostosowany do potrzeb wykładowców } \\
\text { i studentów sprzęt w salach wykładowych } \\
\text { oraz laboratoriach; } \\
\text { - Praca zmianowa - np. wprowadzenie wa- } \\
\text { riantu dwutygodniowego - tydzień zajęć } \\
\text { z jedną grupą, tydzień z inną; } \\
\text { - Optymalizacja czasu trwania zajęć; } \\
\text { - Możliwość prowadzenia zajęć poza po- } \\
\text { mieszczeniami uczelni - np. na zewnątrz; } \\
\text { - Wykorzystywanie narzędzi komunikacji } \\
\text { asynchronicznej; } \\
\text { - Dostęp do Internetu we wszystkich salach; } \\
\text { - Wprowadzenie narzędzi do rzetelnej } \\
\text { weryfikacji wiedzy studenta, np. podczas } \\
\text { egzaminów; } \\
\text { - Organizacja egzaminów stacjonarnych. }\end{array}$ \\
\hline
\end{tabular}


Sposoby udoskonalenia organizacji zajęć dydaktycznych prowadzonych zdalnie (online) - w kontekście zagrożenia epidemicznego COVID-19

\begin{tabular}{|c|c|}
\hline Propozycje studentów & Propozycje wykładowców \\
\hline $\begin{array}{l}\text { - Udostępnianie przez wykładowców po } \\
\text { zajęciach omawianych prezentacji; } \\
\text { - Nawiązywanie dialogu ze studentami, } \\
\text { więcej pytań angażujących grupę; } \\
\text { - Dłuższe przerwy między zajęciami; } \\
\text { - Wspomaganie wykładowców w dosko- } \\
\text { naleniu umiejętności prowadzenia zajęć } \\
\text { zdalnych np. poprzez szkolenia; } \\
\text { - Optymalizacja liczby godzin zdalnych } \\
\text { w jednym dniu; } \\
\text { - Przy zajęciach zdalnych trwających od rana } \\
\text { do wieczora wprowadzić jedną dłuższą } \\
\text { przerwę; } \\
\text { - Bardziej elastyczny czas zajęć; } \\
\text { - Udostępnienie studentom uczelnianego } \\
\text { oprogramowania na prywatnych laptopach; } \\
\text { - Udostępnienie wykładowcom tabletów } \\
\text { graficznych; } \\
\text { - Szkolenie kadry dydaktycznej oraz studen- } \\
\text { tów z obsługi platform, z których korzysta } \\
\text { uczelnia; } \\
\text { - Więcej materiałów w ciekawej formie; } \\
\text { - Lepszą komunikację student-wykładowca } \\
\text { mogłaby umożliwić konieczność włączania } \\
\text { kamer przez studentów; } \\
\text { - Udostępnianie np. nagrań z ćwiczeń } \\
\text { wykonanych przez prowadzącego - z ko- } \\
\text { mentarzem; } \\
\text { mację o zbliżającym się terminie oddania } \\
\text { - Dokiniaprojektu; } \\
\text { - Ujednolicenie używanej platformy do } \\
\text { alnych, podłączania tabletów do pisania itp. } \\
\text { nauczania zdalnego; } \\
\text { - Wprowadzenie ograniczenia lub weryfikacji } \\
\text { liczby godzin rzeczywiście spędzanych nad } \\
\text { zadaniami dla studentów, aby nie były zbyt } \\
\text { długie; } \\
\text { - Lepszy podział zajęć w celu rozłożenia } \\
\text { czasu spędzonego przed ekranem; } \\
\text { - Interaktywny plan zajęć z możliwością } \\
\text { online i możliwością dodawania przez } \\
\text { - }\end{array}$ & 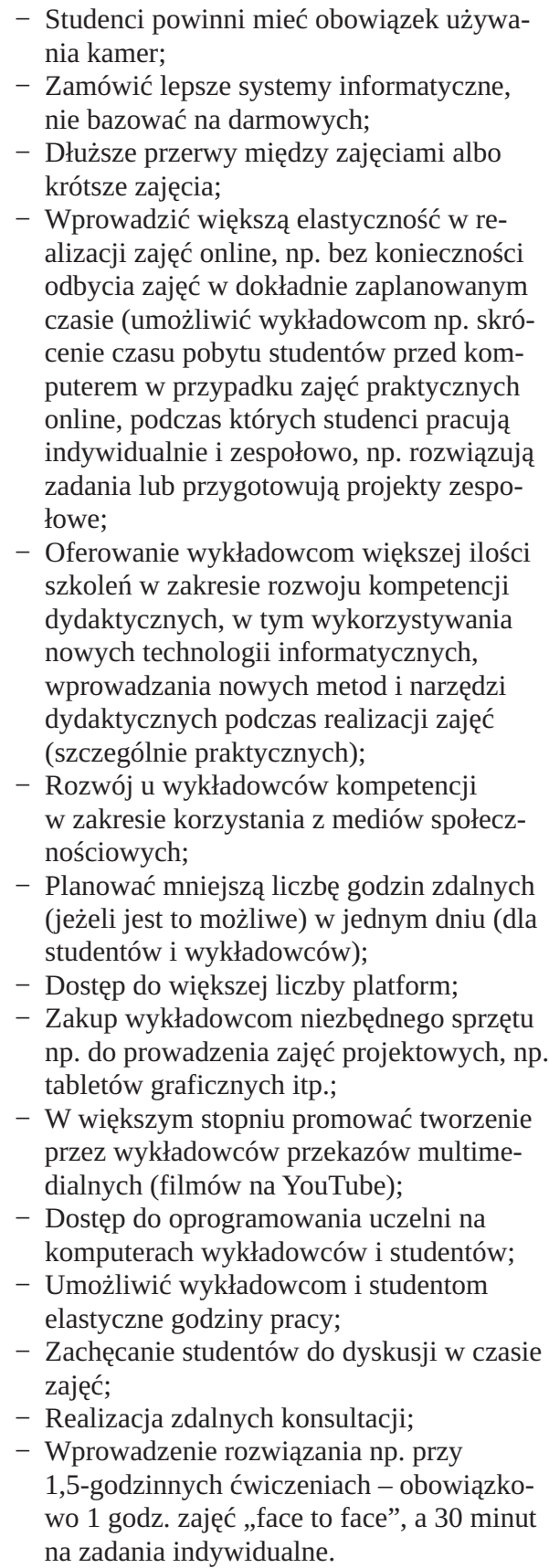 \\
\hline
\end{tabular}




\section{WNIOSKI}

Przeprowadzone badania pozwoliły na wskazanie zarówno tych pozytywnie, jak i negatywnie ocenianych przez studentów i wykładowców aspektów, które składają się na jakość kształcenia akademickiego w dobie ciągłego zagrożenia epidemicznego COVID-19. Przyjęty przez autorkę model badawczy, oparty w dużej części na metodyce Servqual, doprowadził do wskazania występujących różnic pomiędzy oczekiwaniami a ocenami respondentów. Zaletą tej metody jest możliwość dokonania analizy pięciu obszarów badawczych (wymiarów), a w ich ramach licznych (27) elementów (aspektów) wpływających na postrzeganą jakość kształcenia w szkołach wyższych. Taka szczegółowa analiza i porównanie opinii dwóch współpracujących na co dzień stron - studentów i wykładowców - powinna stać się przyczynkiem do wprowadzenia wielu działań na rzecz doskonalenia sposobów realizacji zarówno zajęć stacjonarnych, jak i zdalnych (odbywających się online). W publikacji przedstawiono wiele ciekawych rekomendacji, płynących od obu środowisk. Zaprezentowano też najczęściej wskazywane przez respondentów problemy - co pokazuje skalę trudności, z jakimi muszą współcześnie borykać się zarówno studenci, jak i pracownicy uczelni. Obie grupy wśród najbardziej dokuczliwych problemów wskazały zbyt dużą liczbę godzin spędzonych w jednym dniu przed komputerem. Istotna różnica pomiędzy grupami badanych studentów i wykładowców dotyczy wskazywanych przez nich „,wag” dla ocenianych obszarów (wymiarów). Dla wykładowców sprawą kluczową wpływającą na skuteczność uczenia się przez studentów są ich postawy i komunikacja. Dla studentów są nimi przede wszystkim profesjonalizm wykładowców oraz wymiar materialny.

Zdaniem autorki obecny czas pandemii COVID-19 i doświadczenia edukacyjne z nim związane powinny stać się przyczynkiem do pogłębionych badań i refleksji nad przyszłością kształcenia akademickiego. Optymistyczny jej obraz może wynikać z wielu potencjałów, które jeszcze pewnie długo by się nie ujawniły, gdyby nie konieczność prowadzenia zajęć w trybie zdalnym. Obyśmy skrzętnie zbierane refleksje potrafili wykorzystać w praktyce i dokonywać oczekiwanych przez studentów i wykładowców zmian.

\section{Bibliografia}

Basilaia, G., Kvavadze, D. (2020). Transition to online education in schools during a SARS-CoV-2 coronavirus (COVID-19) pandemic in Georgia. Pedagogical Research, 5 (4), pp. 1-10. DOI: 10.29333/pr/7937. 
Cellary, W. (2020). Edukacja w świetle pandemii. W: Nauczanie po pandemii. Nowe pytania czy nowe odpowiedzi na stare pytania? (s. 15-24). Warszawa: Wydawnictwo SGGW.

Czarkowski, J. (2020a). Elementy dydaktyki dorosłych w perspektywie dystansu społecznego. W: J. Czarkowski, M. Malinowski, M. Strzelec, M. Tana (red.), Zdalne kształcenie akademickie dorosłych w czasie pandemii (s. 93-114). Warszawa: Wydawnictwo DiG.

Czarkowski, J. (2020b). Komunikacja w kształceniu zdalnym dorosłych. W: J. Czarkowski, M. Malinowski, M. Strzelec, M. Tana (red.), Zdalne kształcenie akademickie dorosłych w czasie pandemii (s. 79-92). Warszawa: Wydawnictwo DiG.

Detyna, B. (2018). Efektywność procesu kształcenia - dylematy i propozycje ewaluacji, Marketing i Rynek, 12 (CD), s. 113-123.

Detyna, B., Augustyniak, M. (2010). Ocena jakości usług edukacyjnych w szkole wyższej, na przykładzie kierunku logistyka, z wykorzystaniem metody Servqual. W: J. Szołtysek, M. Jedliński (red.), Logistyka. Współczesne wyzwania, 1 (s. 151-163). Wałbrzych: Wydawnictwo Uczelniane Państwowej Wyższej Szkoły Zawodowej im. A. Silesiusa w Wałbrzychu.

Długosz, P., Foryś, G. (2020). Zdalne nauczanie na Uniwersytecie Pedagogicznym im. Komisji Edukacji Narodowej w Krakowie z perspektywy studentów i wykładowców. Kraków: Wydawnictwo Naukowe Uniwersytetu Pedagogicznego.

Gruszczyńska, E. (2020). Kształcenie wyższe na odległość: jednak w poszukiwaniu nowych odpowiedzi na stare pytania. W: Nauczanie po pandemii. Nowe pytania czy nowe odpowiedzi na stare pytania? (s. 25-32). Warszawa: Wydawnictwo SGGW.

Kraśniewski, A. (2020). O jakości kształcenia w czasach COVID-19: stare odpowiedzi na nowe pytania? W: Nauczanie po pandemii. Nowe pytania czy nowe odpowiedzi na stare pytania? (s. 39-50). Warszawa: Wydawnictwo SGGW.

Leżański, D., Sobolewska, J. (2020). Z perspektywy studentów. W: Nauczanie po pandemii. Nowe pytania czy nowe odpowiedzi na stare pytania? (s. 59-64). Warszawa: Wydawnictwo SGGW.

Lopes, H., McKay, V. (2020). Adult learning and education as a tool to contain pandemics: The COVID-19 experience. International Review of Education, 66. pp. 575-602.

Łaszczyk, J. (2020). Edukacja zdalna - szansa czy konieczność? W: Nauczanie po pandemii. Nowe pytania czy nowe odpowiedzi na stare pytania? (s. 65-72). Warszawa: Wydawnictwo SGGW.

Mazur, J. (2021). Nauczanie zdalne. Oswojenie (nie)znanego. Wpływ pandemii COVID-19 na szkolnictwo wyższe. Raport EduHack 2021. Warszawa: Inkubator Uniwersytetu Warszawskiego.

Murphy, M.P.A. (2020). COVID-19 and emergency eLearning: Consequences of the securitization of higher education for post-pandemic pedagogy. Contemporary Security Policy, 41(3), pp. 492-505. DOI: 10.1080/13523260.2020.1761749.

Petrie, C. (2020). Spotlight: Quality education for all during COVID-19 crisis. Pobrane z: https://hundred.org/en/collections/quality-education-for-all-during-coronavirus.

Piwowarska, E. (2020). Nauczanie po pandemii: szansa na wprowadzenie ważnych zmian w dydaktyce akademickiej. W: Nauczanie po pandemii. Nowe pytania czy nowe odpowiedzi na stare pytania? (s. 117-124). Warszawa: Wydawnictwo SGGW.

Pokhrel, S., Chhetri R. (2021). A Literature Review on Impact of COVID-19 Pandemic 
on Teaching and Learning. Higher Education for the Future, 8, pp. 133-141. DOI: $10.1177 / 2347631120983481$.

Schleicher, A. (2020). The impact of COVID-19 on education - Insights from Education at a Glance. Pobrane z: https://www.oecd.org/education/the-impact-of-covid-19-oneducation-insights-education-at-a-glance-2020.pdf.

Sękowski, P. (2020). Niektóre prawne uwarunkowania organizacji i prowadzenia zajęć zdalnych z zastosowaniem technologii informatycznych. W: J. Czarkowski, M. Malinowski, M. Strzelec, M. Tana (red.), Zdalne kształcenie akademickie dorosłych w czasie pandemii (s. 241-252). Warszawa: Wydawnictwo DiG.

Siemieniecka, D. (2020). Narzędzia społecznościowe w nauczaniu - wskazania do praktyki edukacyjnej w sytuacji koronawirusa COVID-19 - raport z badań pilotażowych. W: J. Czarkowski, M. Malinowski, M. Strzelec, M. Tana (red.), Zdalne kształcenie akademickie dorosłych w czasie pandemii (s. 177-194). Warszawa: Wydawnictwo DiG.

Sintema, E. J. (2020). Effect of COVID-19 on the performance of grade 12 students: Implications for STEM education. EURASIA Journal of Mathematics, Science and Technology Education, 16(7), pp. 1-6. DOI: 10.29333/ejmste/7893.

Strzelec, M. (2020). Rozwój mediów a kształcenie zdalne. W: J. Czarkowski, M. Malinowski, M. Strzelec, M. Tana (red.), Zdalne kształcenie akademickie dorosłych w czasie pandemii (s. 67-78). Warszawa: Wydawnictwo DiG.

Topol, P. (2020). Metody i narzędzia kształcenia zdalnego w polskich uczelniach w czasie pandemii COVID-19 - część 1, dyskusja 2020. Studia Edukacyjne, 58, s. 69-83.Topol, P. (2020). Metody i narzędzia kształcenia zdalnego w polskich uczelniach w czasie pandemii COVID-19 - część 1, dyskusja 2020. Studia Edukacyjne, 58, s. 69-83. 